\title{
Fungsi Pemerintahan Desa Terhadap Pemerataan Pembangunan di Desa Bola Bulu Kecamatan Pitue Riase Kabupaten Sidenreng Rappang
}

\author{
Sapri ${ }^{1}$ \\ Muhammad Ikbal ${ }^{2}$ \\ Sulfikar ${ }^{3}$ \\ Dosen Ilmu Administrasi Publik Unuversitas Muhammadiyah Sidenreng Rappang, Indonesia ${ }^{1,2}$ \\ Mahasiswa Ilmu Administrasi Publik Unuversitas Muhammadiyah Sidenreng Rappang, Indonesia ${ }^{3}$ \\ sapritajuddin3@gmail.com
}

Keyword:

village Government

Functions;

Village Development.

Kata Kunci:

fungsi Pemerintahan

Desa;

Pembangunan Desa.

\begin{abstract}
The purpose of the research is to find out the function of the village government towards equitable development in Bola Bulu Village, Pitu Riase District, Sidenreng Rappang Regency.The research method used is descriptive quantitative research method. The study population was 80 people who received service in Bola Bulu Village, Pitu Riase Sub-District, Sidenreng Rappang District, from the total population of 2426, determining the sample using purposive sampling, by obtaining the sample results in this study of 80 people. Data collection techniques or survey techniques use namely observation, questionnaire / questionnaire, interview, literature study, then the data obtained are collected and analyzed with quantitative descriptive techniques using frequency and percentage tables.The results showed that the variable $(x)$ function of village governance was $55.67 \%$, the category was quite good. Viewed from the Transparency Indicator, $37 \%$ were categorized as poor. Furthermore, the variable (y) Development Equity produced is $67 \%$ good category. Viewed from the Guarantee Indicator, the relationship and consistency of the development process produced is 52\% good enough. While the factors that influence the function of the Village Government on Equitable Development in Bola Bulu Village, Pitu Riase District, Sidenreng Rappang Regency with the results stated that $67 \%$ in this study are in the good category.
\end{abstract}

\begin{abstract}
Abstrak: Tujuan dari penelitian ini adalah untuk mengetahui fungsi pemerintah desa terhadap pemerataan pembangunan di Desa Bola Bulu Kecamatan Pitu Riase Kabupaten Sidenreng Rappang. Metode penelitian yang digunakan adalah metode penelitian deskriptif kuantitatif. Populasi penelitian adalah 80 orang yang mendapat pelayanan di Desa Bola Bulu Kecamatan Pitu Riase Kecamatan Sidenreng Rappang dari total populasi sebanyak 2426 orang, penentuan sampel menggunakan purposive sampling, dengan didapat hasil sampel dalam penelitian ini sebanyak 80 orang. Teknik pengumpulan data atau teknik survey yang digunakan yaitu observasi, angket / angket, wawancara, studi pustaka, kemudian data yang diperoleh dikumpulkan dan dianalisis dengan teknik deskriptif kuantitatif dengan menggunakan tabel frekuensi dan persentase. Hasil penelitian menunjukkan bahwa variabel (x) fungsi pemerintahan desa 55,67\% kategori cukup baik. Dilihat dari Indikator Transparansi, 37\% dikategorikan kurang baik. Selanjutnya variabel (y) Ekuitas Pembangunan yang dihasilkan 67\% kategori baik. Dilihat dari Indikator Penjaminan, hubungan dan konsistensi proses pembangunan yang dihasilkan cukup baik sebesar 52\%, sedangkan faktor-faktor yang mempengaruhi fungsi Pemerintah Desa dalam Pemerataan Pembangunan di Desa Bola Bulu Kecamatan Pitu Riase Kabupaten Sidenreng Rappang dengan hasil menyatakan bahwa 67\% dalam penelitian ini termasuk dalam kategori baik.
\end{abstract}

\section{PENGANTAR}

Pembangunan desa memegang peranan yang penting karena merupakan bagian yang tidak terpisahkan dan pada hakikatnya bersinergi terhadap pembangunan daerah dan nasional. Hal 
tersebut terlibat melalui banyaknya program pembangunan yang dirancang pemerintah untuk pembangunan desa. Hampir seluruh instansi terutama pemerintah daerah mengkomodir pembangunan desa dalam program kerjanya. Tentunya berlandaskan pemahaman bahwa desa sebagai kesatuan geografis terdepan yang merupakan tempat sebagian besar penduduk bermukim. Pembangunan desa memegang peranan yang penting karena merupakan bagian yang tidak terpisahkan dan pada hakikatnya bersinergi terhadap pembangunan daerah dannasional.

Hal tersebut terlihat melalui banyaknya program pembangunan yang di rancang pemerintah untuk pembangunan desa. Hampir seluruh instansi terutama pemerintah daerah mengkomodir pembangunan desa dalam program kerjanya. Tentunya berlandaskan pemahaman bahwa desa sebagai kesatuan geografis terdepan yang merupakan tempat sebagian besar penduduk bermukim. Dalam struktur pemerintahan, desa menempati posisi terbawah, akan tetapi justru terdepan dan langsung berada di tengah masyarakat.

Karenanya dapat di pastikan apapun bentuk setiap program pembangunan dari pemerintah akan selalu bermuara ke desa. Meskipun demikian, pembangunan desa masih memiliki berbagai permasalahan, seperti adanya desa terpencil atau terisolir dari pusat-pusat pembangunan (Centre of excellent). Masih minimnya prasarana social ekonomi serta penyebaran jumlah tenaga kerja produktif yang tidak seimbang, termasuk tingkat

produktivitas, tingkat pendapatan masyarakat dan tingkat pendidikan yang relatif masih rendah.

Pemerintahan desa dalam melaksanakantugasdantanggungjawabnya mempunyai hambatan dan permasalahan. Hambatan dan permasalahan tersebut antara lain meliputi : kurangnya sumber daya manusia perangkat desa, kurangnya sarana dan prasarana kerja, serta penghasilan yang masih rendah. Kita memahami bahwa pembangunan dibutuhkan untuk memecahkan masalah seperti kemiskinan, kesenjangan sosial, pengangguran. Namun pemahaman yang demikian tidak boleh dibiarkan begitu saja tanpa adanya kritik maupun kontrol terhadapnya karena prinsipnya kehadiran pembangunan dapat diasumsikan sebagai satu-satunya cara untuk dapat memecahkan masalah dapat berbalik fakta, seperti adanya kesenjangan sosial ekonomi, politik dan kebudayaan. Bertitik tolak dari permasalahan tersebut, dibutuhkan keterlibatan aktif dan keseriusan dari pemerintahan desa Bola Bulu Kecamatan Pitu Riase Kabupaten Sidenreng Rappang. Dalam memainkan perannya dalam pembangunan desa, dalam proses penanggulannya pemerintahan desa Bola Bulu juga harus melihat setiap kebijakan-kebijakan yang akan di implementasikan dan dilaksankan.

Desa Bola Bulu sampai saat ini masih melakukan pembangunan baik dari segi infrastruktur, suprastruktur dan membenahi pelayanan politik yang sekian lama terbengkalai. Adapun program yang menjadi perhatian lebih dari pemerintah desa adalah pembangunan perbaikan jalan. pentingnya peran masyarakat dalam ikut serta memberikan sumbangsih pikiran tenaga dalam progarm-program pemerintahandesa.

\section{Pemerintahan Desa}

Peranan pemerintahan desa dalam memberdayakan masyarakat bidang pembangunan Infrastruktur menurut Rahardjo Adisasmita (2006: 18) dapat diukur melalui indikator:

a. Pelaksanaan pembangunan infrastruktur yaitu sebuah proses pembangunan untuk meningkatkan kualitas hidup masyarakat.

b. Tersedianya infrastruktur desa.

c. Dapat dinikmati oleh seluruh masyarakat.

d. Transparansi, yaitu keterbukaan penggunaan dana dari pemerintahan desa terhadap pembangunan.

e. Berkelanjutan, yaitu hasil dari pembangunan infrastruktur tersebut harus memiliki pengawasan atau kontrol dari masyarakat sehingga pembangunan tersebut dapat dinikmati secara terus-menerus.

Dari penjelasan diatas penulis dapat menyimpulkan bahwa kewenangan danfungsi pemerintahan desa adalah wewenang dan tanggungjawab yang dimiliki oleh pemerintahan desa sesuai dengan kewenangannya masing-masing. 


\section{Pemerataan Pembangunan}

Indikator perencanaan pembangunan menurut Sjafrizal, (2014:26) adalah sebagai berikut:

a. Mendukung koordinasi antara pelaku pembangunan merupakan keterpaduan antara pelaku pembangunan baik dalam institusi pemerintahan sendiri maupun pemerintahan antar pihak swasta dan masyarakat secara keseluruhan.

b. Menjamin terciptanya integrasi,singkronisasi dan sinergi antar daerah yaitu dapat mendorong proses pembangunan secara lebih cepat dan efisien.

c. Menjamin keterkaitan dan konsistensi antara perencanaan, penganggaran, pelaksanaan dan pengawasan adalah untuk dapat mewujudkan pembangunan sesuai dengan apa yang telah direncanakan semula, perlu dijamin semaksimal mungkin terdapatnya keterkaiatan antara perencanaan, penganggaran,pelaksanaan, dan pengawasan.

d. Mengoptimalkan partisipasi masyarakat dalam perencanaan pembangunan ialah bagaimana partisipasi masyarakat tersebut dapat dimanfaatkan seoptimal mungkin dalam perencanaan.

Menjamin tercapainya sumber daya secara efisien, efektif dan adil merupakan tujuan dan fungsi utama dari perencanaan pembangunan dalam literatur adalah untuk menjamin terwujudnya pengguanaan sumber daya,baik dana dan tenaga secara efektif, efisien dan adil.

\section{METODE PENELITIAN}

Penelitian ini memiliki dua variabel, variabel pertama disebut sebagai variabel bebas yaitu fungsi pemerintah desa dan variabel kedua sebagai variabel terikatnya yaitu pemerataan pembangunan.desain penelitian yang di gunakan adalah deskritif kuantitatif yaitu setiap variable yang di tentukandiukurdengan memberikan simbol-simbol berupa angka-angka yang berbedabeda sesuai kategori informasi yang berkaitan dengan variable-variable tersebut.

\section{HASIL DAN DISKUSI}

Fungsi Pemerintah Desa Hasil penelitian yang menunjukkan tanggapan responden tentang pemerintah desa mempengaruhi masyarakat dalam pemerataan pembangunan dapat digambarkan dalam tabel berikut ini:

1. Fungsi pemerintah desa dalam pelaksanaan pembangunan Infrastruktur.

Berdasarkan data tersebut menunjukkan bawhwa tanggapan responden tentang pemerintah desa dalam pemerataan pembangunan infrastruktur di Desa Bola Bulu adalah 2orang(2,5\%)respondenmenjawabsangat Baik, 40 orang (50 \%) responden menjawab Baik, 30 orang ( $37,5 \%)$ responden menjawab Ragu- ragu, 8 orang $(10 \%)$ responden menjawab tidak baik, dan tidak ada responden yang menjawab sangat tidakbaik.

2. Transparansi merupakan keterbukaan pengunaan dana dari pemerintah desa terhadap pembangunan.

Berdasarkan data tersebut menunjukkan bahwa tanggapan responden tentang fungsi pemerintah desa dalam pembangunan di Desa Bola Bulu adalah tidak ada responden yang menjawab sangat Baik, tidak ada responden yang menjawab Baik, 8 orang (10\%) respondenmenjawabRagu-ragu, 50 orang $(62,5 \%)$ responden menjawab tidak baik,dan22 orang $(27,5 \%)$ responden yang menjawab sangat tidak baik

3. Berkelanjutan merupakan hasil dari pembangunan infrastruktur tersebut harus memiliki pengawasan atau kontrol dari masyarakat sehingga pembangunan tersebut dapat dinikmati secara terusmenerus.

Berdasarkan data tersebut menunjukkan bahwa tanggapan responden tentang fungsi pemerintahdesa dalam pengawasan adalah pembangunan di Desa Bola Bulu adalah 5 orang $(6,25 \%)$ responden menjawab sangat Baik, 30 orang $(37,5 \%)$ responden menjawab Baik,10 
orang $(12,5 \%)$ responden menjawab Ragu-ragu, 35 orang $(43,75 \%)$ responden menjawab tidak baik, dan tidak ada responden yang menjawab sangat tidak baik.

Pemerataan pembangunan Hasil penelitian menunjukkan tanggapan responden tentang dukungan koordinasi antara pelaku pembangunan terhadap perencanaan pembangunan di Desa Bola Bulu.

1. Dukungan koordinasi antara pelaku pembangunan terhadap pemerataanpembangunan.

Berdasarkan data tersebut menunjukkan bahwa tanggapan responden tentang jaminan terciptanya keterkaitan daerah terhadap dukungan koordinasi antara pelaku pembangunan terhadap pemerataan pembangunan di Desa Bola Bulu adalah 3 orang $(3,75 \%)$ responden menjawab sangat Baik,47 orang (58,75\%) responden menjawab Baik, 23 orang (28,75\%) responden menjawab Ragu-ragu, 7 orang $(8,75 \%)$ responden menjawab tidak baik, dan tidak ada responden yang menjawab sangat tidakbaik.

2. Jaminan terciptanya keterkaitan daerah terhadap pemerataan pembangunan di desa BolaBulu

Berdasarkan data tersebut menunjukkan bahwa tanggapan responden tentang jaminan terciptanya keterkaitan daerah terhadap pemerataan pembangunan di Desa Bola Bulu adalah 1 orang $(1,25 \%)$ responden menjawab sangat Baik, 39 orang $(48,75 \%)$ respondenmenjawab Baik, 29 orang $(36,25 \%)$ responden menjawab Ragu-ragu, 11 orang $(13,75 \%)$ responden menjawab tidak baik, dan tidak ada responden yang menjawab sangat tidak baik.

3. Optimalnya partisipasi masyarakatterhadap perencanaan pembangunan di Desa BolaBulu.

Berdasarkan data tersebut menunjukkan bahwa tanggapan responden tentang optimalnya partisipasi masyarakat terhadap perencanaan pembanguna di Desa Bola Bulu adalah 3 orang $(3,75 \%)$ responden menjawab sangatBaik,39 orang $(48,75 \%)$ responden menjawab Baik, 21 orang $(26,25 \%)$ responden menjawab Ragu-ragu, 17 orang $(21,25 \%)$ responden menjawab tidak baik, dan tidak ada responden yang menjawab sangat tidakbaik.

4. Jaminan tercapainya sumber daya secara efisien,efektif dan adil terhadap perencanaan pembangunan di Desa BolaBulu.

Berdasarkan data tersebut di atas menunjukkan bahwa tanggapan responden tentang jaminan terpercayanya sumber daya secara efisien, efektif dan adil terhadap perencanaan pembangunan di Desa Bola Bulu adalah 7 orang $(8,75 \%)$ responden menjawab sangat Baik, 33 orang $(41,25 \%)$ responden menjawab Baik, 27 orang (33,75\%) responden menjawab Ragu-ragu, 13 orang $(16,25 \%)$ responden menjawab tidak baik, dan tidak ada responden yang menjawab sangat tidak baik.Menghadirkan kesimpulan penelitian, implikasi, batasan, dan saran sebagai konsekuensinya. Implikasinya adalah saran praktis dari hasil penelitian. Keterbatasan penelitian meliputi hal-hal yang dapat dilakukan peneliti atau peneliti dalam melakukan penelitiannya. Sedangkan saran penelitian adalah saran untuk penelitian selanjutnya berdasarkan batasan yang tidak dapat dilakukan oleh peneliti dalam penelitiannya.

\section{KESIMPULAN}

Berdasarkan hasil penelitian yang telah diuraikan pada bab diatas dapat disimpulkan bahwa:

1. Pada variabel bebas Fungsi Pemerintahan Desa rekapitulasi dari tiga indikator variabel berada pada persentase $55,67 \%$ kategori baik, adapun persentase tertinggi berada pada indikator Pelaksanaan Pembangunan infrastruktur 69\%, kategori baik, dan terendah pada indikator Transparansi dengan persentase 37\%, kategori kurang baik. Pada variabel terikat Pemerataan Pembangunan rekapitulasi darilimaindikator variabel berada pada persentase $67 \%$ kategori baik 
2. Faktor-faktor yang mempengaruhi Fungsi Pemerintahan Desa terhadap Pemerataan Pembangunan di Desa Bola Bulu Kecamatan Pitu Riase Kabupaten Sidenreng Rappang dengan hasil menyatakan $67 \%$ dalam penelitian ini berada pada kategori baik.

\section{REFERENSI}

Adisasmita, Rahardjo, 2016. Membangun Desa Partisipatif. Graha Ilmu. Yokyakarta

Ahmad, Jamaluddin. 2015. Metode Penelitian Administrasi Publik dan Teori dan Aplikasi. Penerbit Gava Media. Yokyakarta.

Beratha.1991, Desa Masyarakat Desa Dan Pembangunan Desa,Ghalia Indonesia,Jakarta.

Daldjoeni, 2004. Pedesaan,Lingkungan dan Pembangunan, Bandung : PT. Alumni Hamdi, Asep Saepul. E.

Baharuddin. 2014. Metode Penelitian Kuantitatif Aplikasi Dalam Pendidikan, ( Yogyakarta: Deepublisher).

Isbandi.(2014), perencanaan partisipasi berbasis Aset Kominitas. Dari Pemikiran menuju penerapan. Jakarta: FISIP UI Press.

Kartasasmita, 2013. Pembangunan Untuk Rakyat: Memadukan Pertumbuhan Dan Pemerataan, Jakarta: Pustaka Cidessino.

Kartohadikusumo, 1998, Desa Balai Pustaka, Jakarta.

Ndraha, Taliziduhu.2002.Ilmu Pemerintahan (Kybernology).RinekaCipta. Jakarta.

Nazir .2005. Metode Penelitian. Galia Indonesia Jakarta.

Nurcholis, Hanif. 2010.Teori dan Praktek Pemerintahan dan otonomi daerah. PT. Gramedia Widiasarana Indonesia. Jakarta.

Rasyid, Ryaas. 2000. Makna Pemerintahan: Tinjauan Dari Segi Etika dan Kepemimpinan. Yarif Watampone. Jakarta.

Siagian, Sondang P. 2008. Adminitrasi Pembangunan. Jakarta : PT. Bumi Aksara.

Sjafrizal,2014, Perencanaan Pembangunan Daerah Dalam Era Otonomi, Raja Grafindo Persada, Jakarta.

Sugiyono. 2014. Metode Penelitian pendidikan (pendekatan kuantitatif, kualitatif dan R \& D. Bandung:Alfabeta.

Sugiyono. 2009. Metode Penelitian Administrasi. Alfabeta. Bandung.

Tjokrowinoto, Moeljarto. 2007. Pembangunan Dilema dan Tantangan. Yogyakarta :Pustaka Pelajar. 